\title{
UROPHYSIAL AND PITUITARY EXTRACTS FOR SPAWNING INDUCTION IN TELEOSTS.
}

\author{
EXTRATOS UROFISÁRIO E HIPOFISÁRIO PARA INDUÇÃO DA DESOVA \\ EM TELEÓSTEOS.
}

\author{
Everton Rodolfo Behr ${ }^{1}$ Bernardo Baldisserotto ${ }^{2}$ Walter Garcia-Parra ${ }^{3}$ \\ Deodoro Atlante Brandão ${ }^{4}$ Zolst Herke $^{5}$
}

\begin{abstract}
Several studies have suggested that the caudal SUMMARY neurosecretory system could act on fish reproduction. The aim of this study was to compare the effect of urophysial extract (UE) and carp pituitary homogenate $(\mathrm{CPH})$ on the induction of spawning in Hoplias malabaricus, Rhamdia quelen and Cyprinus carpio. The amount of UE injected was 1.0 to $3.0 \mathrm{mg} / \mathrm{kg}$ L.W. (single dose) and CPH 3.0 to $4.0 \mathrm{mg} / \mathrm{kg} \mathrm{L.W.} \mathrm{(two} \mathrm{doses).}$ The application of UE had no effect on spawning induction, while CPH improved spawning of all studied species.
\end{abstract}

Key words: fish-culture, induced reproduction, urophysis,
pituitary, spawning. RESUMO

Vários trabalhos sugerem que a urófise poderia atuar de alguma maneira na reprodução dos peixes. Este trabalho tem por objetivo comparar o efeito do extrato urofisário $(U E) e$ do extrato homogeneizado de hipófise de carpa $(\mathrm{CPH})$ na reprodução induzida de Hoplias malabaricus, Rhamdia quelen $e$ Cyprinus carpio. A concentração do UE variou de 1,0 a 3,0mg/kg P.V. em uma única dose. A concentração do CPH variou entre 3,0 e 4,0mg/kg P.V., em duas doses. A aplicação do UE não apresentou resposta positiva na indução da desova, enquanto que o CPH mostrou-se eficaz como agente indutor em todas as espécies testadas.

Palavras-chave: piscicultura, reprodução induzida, urófise, hipófise, desova.

Presently, there are several techniques of hormonal intervention to induce vitellogenesis, spermiogenesis, final maturation, spermiation, ovulation, and spawning (CAROLSFELD, 1989). Hormone-induced spawning has important practical advantages because it facilitates prediction of spawning time and permits its occurrence under controlled conditions, improving fingerlings production. Spawning can be induced by injection of pituitary extract, human chorionic gonadotropin, gonadotropin releasing hormone $(\mathrm{GnRH})$ or sexual steroids (LEGENDRE et al., 1996).

Several studies have suggested that caudal neurosecretory system (CNS) could act on fish reproduction (BERLIND, 1973; LEDERIS, 1973; SHARMA \& SHARMA, 1975; FERNANDES \& MIMURA, 1983; BERN; 1990; LEONARD et al., 1993). However, the effect of urophysial extracts (UE) (extracts from the urophysis, a neurohemal organ of the CNS) or of urotensins I and II (hormones produced by the CNS) on teleost spawning induction have not been investigated. The aim of this study was to compare the effect of UE and $\mathrm{CPH}$ on the induction of spawning of three freshwater teleost species.

Specimens of Hoplias malabaricus, Rhamdia quelen and Cyprinus carpio were collected at the Fish Culture Sector of the Universidade Federal de Santa Maria or at nearby ponds during the reproductive season (November to February). Fishes were selected and sex was determined. An ovarian biopsy was made in the

\footnotetext{
${ }^{1}$ Zootecnist, Master in Ecology, graduate in Zoology, Pontifícia Universidade Católica do Rio Grande do Sul.

${ }^{2}$ Oceanologist, Doctor, Adjunct Professor, Departamento de Fisiologia, Universidade Federal de Santa Maria (UFSM), 97105-900, Santa Maria, RS. Autor para correspondência.E.mail - bernardo@ccs.ufsm.br

${ }^{3}$ Zootecnist, Master in Animal Husbandry, graduate in Freshwater Biology and Fisheries, Instituto Nacional de Pesquisas da Amazônia

${ }^{4}$ Biologist, PhD, Full Professor, Departamento de Zootecnia - UFSM.

${ }^{5}$ Biologist, PhD, Full Professor, Departamento de Zootecnia - UFSM. 
selected females $(0.35$ to $4.0 \mathrm{~kg}$, depending on species) to verify the final maturation of the oocytes. This parameter was determined by the migration of the nucleus and seminal vesicle. Biopsies were made prior the hormonal treatment.

Some mature specimens of $\boldsymbol{H}$. malabaricus were sacrificed to supply the urophysis. The UE was prepared according to ICHIKAWA (1980). Dried carp pituitaries were furnished by Agrober (Hungary) and the pituitary extract (CPH) was prepared according to WOYNAROVICH \& HORVÁTH (1983): pituitaries were grinded and $0.7 \% \mathrm{NaCl}$ was added. This mixture was stirred for $10 \mathrm{~min}$ and let to precipitate. Only the supernatant was used. Maximum volume injected of both extracts was $1 \mathrm{ml} / \mathrm{L} . \mathrm{W}$. Number of induced fishes, doses, and intervals between injections are listed in table 1 .

Two doses were administered in the treatments with $\mathrm{CPH}$ : the first corresponding to $10 \%$ of the total doses and the second corresponding to $90 \%$ of the total doses. After injection of the extracts the specimens were maintained in pairs, except for C. carpio when males and females were maintained separated until extrusion time. Approximately 12 hours after the second dose, all females that did not spawn were submitted to extrusion. Fishes that received injection of UE did not spawn even with the aid of extrusion procedures, whereas all those treated with $\mathrm{CPH}$ spawned.

Urotensin II content in the urophysis of Catostomus commersoni (LEDERIS, 1973) and the amount of neurosecretion in the urophysis of Rita rita (SHARMA \& SHARMA, 1975) and Geophagus brasiliensis (FERNANDES \& MIMURA, 1983) increased during the 2-3 months preceding spawning. However, in Ictalurus punctatus, Fundulus heteroclitus, and Leuciscus rutilus, there were no seasonal differences in CNS neuron stainability (BERLIND, 1973). The UE cause contractions of ovary and oviduct of mature Lebistes, as well as on Gillichthys mirabilis sperm duct smooth muscle. In addition, urotensin II induced dose-dependent contractions of $\boldsymbol{F}$. heteroclitus ovarian smooth muscle (LEONARD $\boldsymbol{e}$ t al. 1993). Therefore, it is possible that the lack of effect of UE on spawning induction was due to the fact that CNS actions on reproduction is related only with stimulation of oviduct and sperm duct contractions to promote oocyte and sperm extrusion, but not to final oocyte maturation as for pituitary extract.

UE proved to be unreliable for spawning induction, at least in the species used in this experiment. However, additional studies of
Table 1 - Data concerning spawning induction in Hoplias malabaricus, Rhamdia quelen, and Cyprinus carpio.

\begin{tabular}{lccc}
\hline Treatment & $\begin{array}{c}\text { Number of } \\
\text { females }\end{array}$ & Dose $(\mathrm{mg} / \mathrm{kg})$ & $\begin{array}{c}\text { Interval between } \\
\text { doses }(\mathrm{h})\end{array}$ \\
\hline H. malabaricus & 3 & 4.0 & \\
CPH & 3 & 3.0 & 12 \\
UE & 5 & 3.5 & - \\
R. quelen & 6 & 2.0 & 12 \\
CPH & & & - \\
UE & 5 & 3.0 & 12 \\
C. carpio & 3 & 1.0 & - \\
CPH & & & \\
UE & 5 & & \\
& & &
\end{tabular}

$\mathrm{CPH}$ - carp pituitary extract

UE - urophysial extract

spawning induction with UE or urotensins associated with the administration of pituitary extract may show interesting results.

\section{REFERENCES}

BERLIND, A. Caudal neurosecretory system: a physiologist's view. American Zoologist, v.13, n.3, p.759-770, 1973.

CAROLSFELD, J. Reproductive physiology \& induced breeding of fish as related to culture of Colossoma. In: HERNÁNDEZ, R.A. Cultivo de Colossoma. Bogotá: Guadalupe, 1989. p.37-64.

FERNANDES, M.N., MIMURA, O.M. Caudal neurosecretory system of the Brazilian freshwater teleost Geophagus brasiliensi (Quoy \& Gaimard, 1824), seasonal changes. Boletim de Fisiologia Animal, v.2, p.31-39, 1983.

ICHIKAWA, T. Antidiuretic activity of teleost urophysial extracts in the rat. Journal of Comparative Physiology, v.135, p.183-189, 1980.

LEDERIS, K. Current studies on urotensins. American Zoologist, v.13, p.771-773, 1973.

LEGENDRE, M., LINHART, R., BILLARD, R. Spawning and management of gametes, fertilized eggs and embryos in Siluroidei. Aquatic Living Resources, v.9, Hors series, p.59-80, 1996.

LEONARD, J.B.K., BARTLEY, S.M., TAYLOR, M.H. Effects of ions and bioactive substances on ovarian contraction in Fundulus heteroclitus. Journal of Experimental Zoology, v.267, n.4, p.468-473, 1993.

SHARMA, S., SHARMA, A. A note on the cauda Neurosecretory system and seasonal changes in the urophysis of Rita rita. Canadian Journal of Zoology, v.53, p.357360, 1975.

WOYNAROVICH, E., HORVÁTH, L. A propagação artificial de peixes de águas tropicais. Brasília FAO/CODEVASF/CNPq, 1983. 220 p. 